\title{
PERBANDINGAN STRUKTUR DAN BIAYA BANGUNAN RANGKA ATAP ANTARA MATERIAL KAYU \& BAJA RINGAN (Study Kasus Gedung Fakultas Teknik dan IImu Komputer UNISI)
}

\author{
Gita Muhtarida \\ Program Studi Teknik Sipil, Fakultas Teknik dan Ilmu Komputer, Universitas Islam Indragiri \\ Email: gita.muchtarida@gmail.com
}

\begin{abstract}
Along with the development of science and technology, the use of wood construction specifically as the structure of the roof frame has begun to be replaced by cold-formed steel construction because the need for wood as the base of roof truss is increasing and the scarcity of trees with good wood quality makes the wood difficult to obtain and the price too become relatively expensive.Comparison of the structure of cold-formed steel roof truss and wooden roof truss is carried out with the load calculation stages in accordance with SKBI 1987 with a combination of loading in accordance with SNI 1729-2002 regulations and SNI 03-2000. Then analyzed using methode of joint to produce rod forces and from these results planned dimensions for the compressive rod and pull rod. Cost calculation is used with SNI analysis method.The results of the calculation of the structure of cold-formed steel roof truss are obtained by the profile of $C .75 .75$, while the structure of the wooden roof truss is obtained wood dimensions of the size of $7 / 10$. The cost of a cold-formed steel roof frame is $R p$. 91,316,000.00, while the cost of wooden roof truss is Rp. 52,972,000. This fee has a disagreement of $R p .38,164,000.00$. Although relatively more expensive, the use of coldformed steel material has several advantages that are not worshiped by wood material.
\end{abstract}

Keywords: Roof frame, cold-formed steel, wood, cost, structure

\begin{abstract}
Abstrak
Seiring dengan perkembangan ilmu pengetahuan dan teknologi, penggunaan konstruksi kayu khususnya sebagai struktur rangka atap sudah mulai digantikan dengan konstruksi baja ringan karena kebutuhan akan kayu sebagai bahan dasar rangka atap semakin meningkat dan semakin langkanya pohon dengan kualitas kayu yang baik menyebabkan kayu susah didapat dan harganya pun menjadi relatif mahal.

Perbandingan struktur rangka atap baja ringan dan rangka atap kayu dilakukan dengan tahapan perhitungan beban sesuai dengan SKBI 1987 dengan kombinasi pembebanan sesuai dengan peraturan SNI 1729-2002 dan SNI 03-2000. Kemudian dianslisis dengan menggunakan metode titik buhul untuk menghasilkan gaya-gaya batang dan dari hasil tersebut direncanakan dimensi untuk batang tekan dan batang tarik. Perhitungan biaya yang digunakan dengan metode analisa SNI.

Hasil perhitungan struktur rangka atap baja ringan diperoleh profil C. 75.75 , sedangkan struktur rangka atap kayu diperoleh dimensi kayu ukuran 7/10. Biaya pada rangka atap baja ringan yaitu Rp. 91.316.000,00, sedangkan biaya pada rangka atap kayu yaitu Rp. 52.972.000. Biaya ini berselisih Rp. 38.164.000,00. Meskipun relatif lebih mahal, pemakaian material baja ringan memiliki beberapa kelebihan yang tidak dipuyai oleh material kayu.
\end{abstract}

Kata kunci: Rangka atap, baja ringan, kayu, biaya, struktur

\section{PENDAHULUAN}

Konstruksi atap merupakan salah satu bagian paling atas dari struktur bangunan seperti pada bangunan sekolah, perkantoran, rumah sakit, rumah tinggal, tempat ibadah, ruang serba guna, pabrik, gudang, dan lainlain yang berfungsi sebagai pelindung ruangan yang ada di bawahnya dari suhu (sinar matahari), cuaca (panas, hujan, angin) dan benda-benda lain yang bisa jatuh masuk 
ke dalam ruangan yang dilindunginya. Seiring dengan perkembangan teknologi dan kebutuhan pada bidang konstruksi, kita dihadapkan pada berbagai pilihan dalam penggunaan material konstruksi bangunan. Pilihan atas suatu material bangunan tergantung dari sifat-sifat teknis, ekonomis, dan dari keindahan. Material yang digunakan untuk konstruksi atap turut menentukan kenyamanan saat dihuni. Seiring perkembangan jaman, kebutuhan akan kayu sebagai bahan dasar rangka atap semakin meningkat namun tidak diiringi dengan kualitas dan kuantitas kayu itu sendiri. Semakin langkanya pohon terutama pohon dengan kualitas kayu yang baik menyebabkan harga kayu menjadi relatif mahal.

Berkat perkembangan teknologi baru, kita dapat sedikit bersyukur karena dapat membantu mengurangi penggundulan hutan yang merupakan paru-paru dunia, terlihat pada perkembangan penggunaan bahan konstruksi atap yang tidak lagi hanya menggunakan kayu, tapi sebagian besar pembangunan kontruksi struktur atap sekarang menggunakan rangka baja ringan sehingga dapat menjaga ketersedian kayu yang saat ini gencar dilakukan sosialisasi oleh pemerintah untuk menghadapi pemanasan global.

Sebagai bahan konstruksi bangunan, kayu sudah dikenal dan banyak dipakai sebelum orang mengenal beton dan baja. Pemakaian kayu tersebut harus memenuhi syarat; mampu menahan bermacam-macam beban yang bekerja dengan aman dalam jangka waktu yang direncanakan, mempunyai ketahanan dan keawetan yang memadai melebihi umur pakainya, serta mempunyai ukuran penampang dan panjang yang sesuai dengan pemakainnya dalam konstruksi. Penggunanan material kayu memiliki kelemahan-kelemahan antara lain kualitas kayu yang tidak merata, pelapukan yang disebabkan oleh serangan rayap, memuai ataupun menyusut karena perubahan cuaca, mudah terbakar, dan langkanya material kayu saat ini. Sedangkan material baja ringan dinilai lebih baik dilihat dari segi kekuatan, anti rayap, serta pemasangannya pun lebih cepat. Selain kekuatan yang tidak kalah kuat dibanding kayu, baja ringan juga mempunyai berat yang jauh lebih minim jika dibandingkan dengan menggunakan kayu sehingga dapat mengurangi beban yang dipikul oleh bangunan.

Berdasarkan pertimbangan yang telah dikemukakan di atas, maka pada Tugas Akhir ini dilakukan penelitian mengenai analisis struktur rangka atap dengan menggunakan material kayu dan baja ringan, serta menganalisis biaya pada kedua meterialnya pada konstruksi atap bangunan Gedung Fakultas Teknik dan Ilmu Komputer UNISI, yang nantinya hasil analisis tersebut dapat dilihat perbandingan antara kedua material tersebut sehingga terciptanya suatu konstruksi kuda-kuda yang aman, hemat, kuat, dan memberikan kemudahan dalam pelaksanaanya.

\section{TINJAUAN PUSTAKA}

Konstruksi rangka atap adalah suatu bentuk konstruksi yang berfungsi untuk menyangga konstruksi atap yang terletak di atas kuda-kuda tersebut. Pada intinya, atap adalah bagian paling atas bangunan yang memberikan perlindungan bagian bawahnya terhadap cuaca, panas, hujan, dan terik matahari. Fungsi rangka atap yang lebih spesifik adalah menerima beban oleh bobot sendiri, yaitu beban kuda-kuda dan bahan pelapis berarah vertikal kemudian meneruskannya pada kolom dan pondasi, serta dapat berfungsi untuk menahan tekanan angin muatan yang berarah horizontal pada gevel (Felix Yap, 2001).

Setiap susunan rangka batang struktur atap haruslah merupakan satu kesatuan bentuk yang kokoh yang nantinya mampu memikul beban yang bekerja padanya tanpa mengalami perubahan (Wicaksono, 2011).

\subsection{Struktur Rangka Atap Baja Ringan}

Rangka atap baja ringan merupakan susunan rangka batang hasil pabrikasi yang membentuk suatu sistem dengan perakitan dan perhitungannya menggunakan bantuan software komputer. Bahan yang digunakan adalah baja bermutu tinggi yang tipis dan ringan.

Profil baja ringan adalah komponen yang berkualitas struktural dari lembaran baja yang dibentuk model tertentu dengan proses pressbraking atau roll forming (Suhu tidak diperlukan dalam proses pembentukan (tidak seperti baja hot-rolled), oleh sebab itu disebut cold-formed. Biasanya baja cold-formed merupakan komponen yang tipis, ringan, mudah untuk diproduksi, dan murah dibandingkan baja hotrolled (Mutawalli, 2007).

Standar yang digunakan untuk konstruksi atap baja ringan menggunakan kode G550, secara teknis berarti kekuatan leleh minimum (akibat gaya tarik) adalah $550 \mathrm{MPa}$ dan tegangan maksimun juga 550 MPa (Wicaksono, 2011).

Rangka atap baja ringan memiliki aturanaturan struktur dalam pemasangannya yang harus sesuai dengan aturan teknis. Komposisi 
rangka atap baja ringan beragam, ini tentunya disesuaikan dengan jenis profil yang dipakainya.

Elemen dari struktur atap baja ringan adalah kuda-kuda, reng, sekrup, dan jurai dalam. Jarak antar kuda-kuda tergantung pada berat penutup atap. Semakin berat beban dari penutup atap maka akan semakin rapat jarak kudakudanya. Misalnnya dengan menggunakan penutup atap genteng beton, jarak antar kudakudanya dapat mencapai 1,4 m. Ketebalan bahan untuk kuda-kuda berkisar 0,75-1 mm, sedangkan ketebalan untuk reng antara 0,4-0,7 mm.

Penggunaan baja ringan sebagai struktur rangka kuda-kuda dan rangka atap memiliki kelebihan dan kekurangan, adapun kelebihan dari struktur atap baja ringan ini antara lain:

1. Bobotnya ringan dibanding dengan struktur kayu sehingga beban yang harus ditanggung oleh struktur bawah atap lebih ringan.

2. Tahan terhadap karat, rayap, serta perubahan cuaca dan kelembaban.

3. Baja ringan bersifat tidak mudah terbakar.

4. Tidak memuai dan menyusut.

5. Pemasangannya relatif mudah dan cepat dibandingkan dengan struktur kayu karena merupakan satu rangkaian.

6. Tidak memerlukan pengecatan.

7. Bahan ini dapat dibuat dengan bermacam bentangan (panjang atau lebar atap).

Sementara kekurangan struktur atap baja ringan ini antara lain:

1. Memerlukan penutup plafon di bawahnya karena struktur baja ringan tidak dapat diexpose.

2. Bentuk atap tidak sefleksibel kayu yang mudah dipotong dan dibentuk.

3. Perhitungan struktur harus tepat dan memerlukan pengawasan yang teliti pada saat pemsangannya karena kesalahan salah satu bagian struktur akan merusak bagian lainnya.

4. Harga per meter atap baja ringan cenderung lebih mahal.

\subsection{Struktur Rangka Atap Kayu}

Konstruksi rangka atap kayu adalah suatu konstruksi yang berfungsi sebagai penahan beban penutup atap, yang melindungi penghuni rumah dari panas matahari, angin, dan air hujan, yang strukturnya terbuat dari rangka kayu. Kayu berasal dari berbagai jenis pohon memliliki sifat-sifat umum, yaitu sifat yang menyebabkan kayu selalu dibutuhkan. Sifatsifat utama tersebut ialah kayu bisa digunakan untuk konstruksi atap. Kayu merupakan bahan mentah yang mudah diproses, mempunyai sifat-sifat spesifik yaitu sifat elastis, ulet mempunyai ketahanan terhadap pebebanan yang tegak lurus dengan seratnya. Sifat-sifat ini tidak dipunyai oleh bahan-bahan baja, beton, atau bahan-bahan lain yang bisa dibuat oleh manusia (Iswanto, 2007).

Penggunaan kayu sebagai struktur rangka atap kuda-kuda memiliki kelebihan dan kekurangan, dimana hal ini tidak telepas dari sifat-sifat struktur kayu itu sendiri. Adapun kelebihannya antara lain :

1. Kayu merupakan bahan bangunan alam, artinya dapat diperoleh di alam bebas tanpa harus dibuat atau diolah di pabrik.

2. Proses pengerjaan konstruksi kayu dapat dilakukan dengan mudah dan peralatan yang digunakan juga sederhana.

3. Merupakan isolasi panas, sehingga bangunan yang banyak menggunakan bahan kayu akan terasa sejuk dan nyaman.

4. Mempunyai daya tahan tinggi terhadap kimia.

5. Kayu merupakan isolator terhadap aliran listrik.

6. Mudah dibongkar pasang dan apabila kayu tersebut masih bagus maka dapat dipakai lagi untuk keperluan yang lain.

7. Bahan bangunan yang banyak disukai oleh tukang lokal.

Selain itu, kayu juga memiliki kekurangan antara lain:

1. Bentang satu kayu tidak bisa terlalu panjang dan kekuatan kayu pun tidak seragam walaupun dari jenis pohon yang sama.

2. Kekuatan dan keawetan kayu sangat tergantung dari jenis dan umur pohonnya.

3. Kayu dapat memuai dan menyusut, tergantung kadar air kandungannya. Bila kandungan airnya banyak kayu akan memuai dan bila kandungan airnya sedikit kayu akan menyusut.

4. Pada pembebanan dalam jangka waktu yang lama, suatu balok akan mengalami lendutan yang relatif besar.

5. Mudah terbakar jika tersulut api, sehingga bangunan yang banyak memakai bahan kayu dan apabila terbakar sulit dipadamkan karena api mudah menjalar.

6. Kayu cepat rusak oleh pengaruh alam, seperti hujan/ air menyebabakan kayu cepat lapuk dan panas matahari menyebabkan kayu retak-retak.

7. Kayu juga mudah lapuk akibat jamur dan dimakan serangga-serangga kecil seperti rayap, bubuk dan kumbang. Hal ini dapat dicegah dengan cara mengawetkan kayu menggunakan bahan kimia dan menjaga setiap bagian kayu tetap kering.

8. Kayu makin sulit didapatkan, akibatnya harganya makin mahal.

9. Bobot cenderung lebih besar dan berat.

10.Sisa material cenderung banyak. 


\section{METODOLOGI PENELITIAN}

Metodologi merupakan penjelasan yang akan digunakan dalam penyusunan Tugas Akhir ini, digambarkan dalam bagan alir (flow chart) di bawah ini.

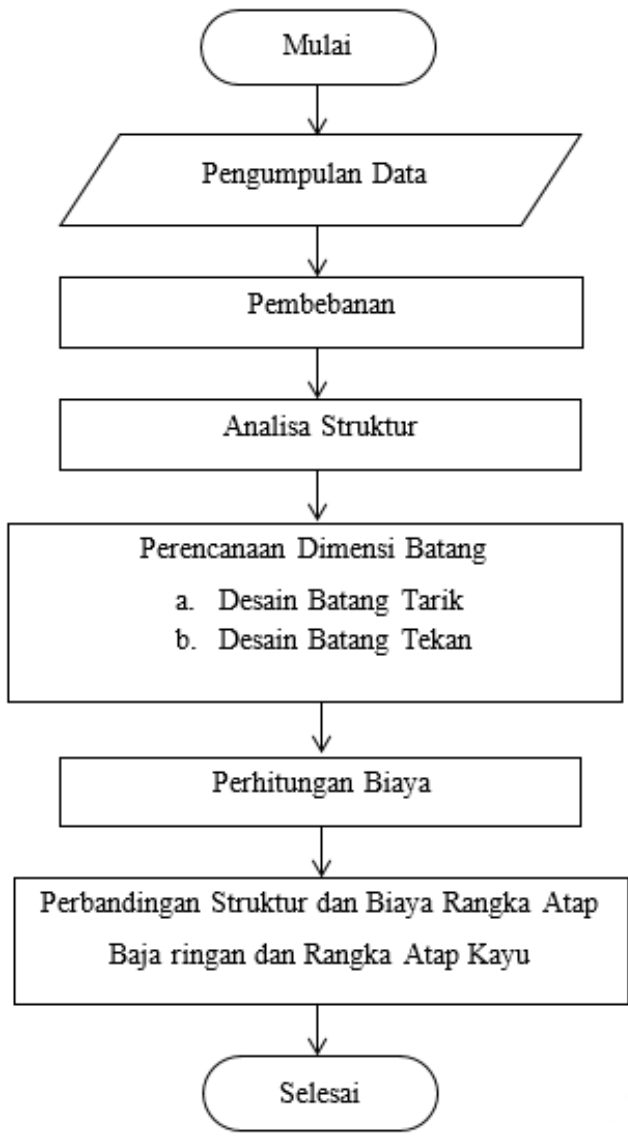

Gambar 1 Flow Chart Metodologi Penelitian. (Sumber: Data Olahan)

\section{HASIL DAN PEMBAHASAN}

\subsection{Perencanaan Rangka Atap Baja Ringan}

Direncanakan sebuah gedung yang luas atapnya $16,00 \mathrm{~m} \times 10,50 \mathrm{~m}$, untuk baja ringan direncanakan jarak antar kuda-kuda yaitu $1,39 \mathrm{~m}$.

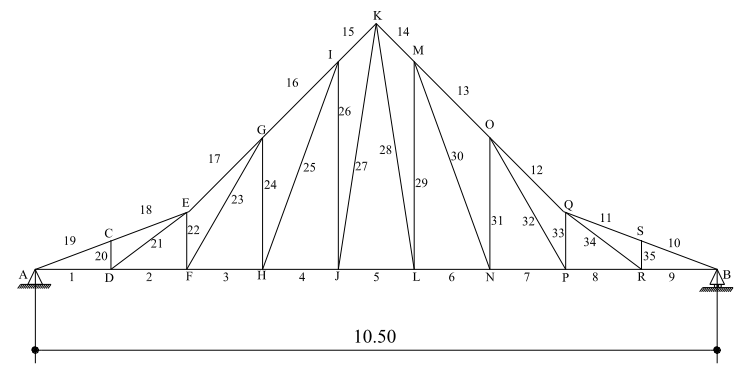

Gambar 2 Rangka Atap Baja Ringan
Hasil perhitungan gaya batang pada rangka atap baja ringan dapat dilihat pada tabel berikut ini :

Tabel 1 Gaya Batang pada Struktur Rangka Atap Baja Ringan

\begin{tabular}{|c|c|c|c|c|}
\hline \multirow{2}{*}{ No. } & \multirow{2}{*}{$\begin{array}{c}\text { No } \\
\text { Batang } \\
\text { (S) }\end{array}$} & \multicolumn{2}{|c|}{ Gaya Batang } & \multirow{2}{*}{$\begin{array}{c}\text { Pjg. } \\
\text { Batang }\end{array}$} \\
\hline & & Tekan & Tarik & \\
\hline 1 & $\mathrm{~S} 1=\mathrm{S} 9$ & - & 1171,15 & 1,17 \\
\hline 2 & $\mathrm{~S} 2=\mathrm{S} 8$ & - & 472,60 & 1,17 \\
\hline 3 & $\mathrm{~S} 3=\mathrm{S} 7$ & $-81,44$ & - & 1,17 \\
\hline 4 & $\mathrm{~S} 4=\mathrm{S} 6$ & $-349,27$ & - & 1,17 \\
\hline 5 & S5 & $-618,38$ & - & 1,17 \\
\hline 6 & $\mathrm{~S} 10=\mathrm{S} 19$ & $-1247,24$ & - & 1,25 \\
\hline 7 & $\begin{array}{l}\mathrm{S} 11 \\
\mathrm{~S} 18\end{array}=$ & $-1247,24$ & - & 1,24 \\
\hline 8 & $\begin{array}{l}\text { S12 } \\
\text { S17 }\end{array}$ & $-668,45$ & - & 1,64 \\
\hline 9 & $\begin{array}{l}\mathrm{S} 13 \\
\mathrm{~S} 16\end{array}$ & - & 115,19 & 1,65 \\
\hline 10 & $\begin{array}{l}\mathrm{S} 14 \\
\mathrm{~S} 15\end{array}$ & - & 494,02 & 0,78 \\
\hline 11 & $\mathrm{~S} 20=\mathrm{S} 35$ & $-204,89$ & - & 0,45 \\
\hline 12 & $\begin{array}{l}\text { S21 } \\
\text { S34 }\end{array}$ & - & 743,94 & 1,49 \\
\hline 13 & $\begin{array}{l}\text { S22 } \\
\text { S33 }\end{array}$ & $-500,57$ & - & 0,87 \\
\hline 14 & $\begin{array}{l}\text { S23 } \\
\text { S32 }\end{array}$ & - & 783,65 & 2,26 \\
\hline 15 & $\begin{array}{l}\text { S24 } \\
\text { S31 }\end{array}$ & $-206,68$ & - & 2,02 \\
\hline 16 & $\begin{array}{l}\text { S25 } \\
\text { S30 }\end{array}$ & - & 378,82 & 3,37 \\
\hline 17 & $\begin{array}{l}\text { S26 } \\
\text { S29 }\end{array}$ & $-202,58$ & - & 3,19 \\
\hline 18 & $\begin{array}{l}\text { S27 } \\
\text { S28 }\end{array}$ & - & 380,64 & 3,80 \\
\hline
\end{tabular}

(Sumber: Data Olahan)

Hasil perhitungan biaya rangka atap baja ringan dapat dilihat pada tabel berikut :

Tabel 2 Perhitungan Biaya Rangka Atap Baja Ringan

\begin{tabular}{|c|l|rr|}
\hline NO. & \multicolumn{1}{|c|}{ URAIAN } & \multicolumn{2}{|c|}{ JUMLAH HARGA } \\
\hline 1 & Main Truss C.75 & Rp & $12.768 .000,00$ \\
\hline 2 & Reng (U Type) & Rp & $7.912 .000,00$ \\
\hline 3 & Screw M5.5 $\times 20$ & $\mathrm{Rp}$ & $10.199 .700,00$ \\
\hline 4 & Screw M4.8 $\times 16$ & $\mathrm{Rp}$ & $5.583 .150,00$ \\
\hline 5 & Dynalbolt & $\mathrm{Rp}$ & $240.000,00$ \\
\hline 6 & $\begin{array}{l}\text { Genteng Metal } \\
0,30 \mathrm{~mm}\end{array}$ & $\mathrm{Rp}$ & $18.900 .000,00$ \\
\hline
\end{tabular}




\begin{tabular}{|c|l|rr|}
\hline NO. & \multicolumn{1}{|c|}{ URAIAN } & \multicolumn{2}{|c|}{ JUMLAH HARGA } \\
\hline 7 & Paku Screw & $\mathrm{Rp}$ & $3.780 .000,00$ \\
\hline 8 & $\begin{array}{l}\text { Nok Genteng } \\
\text { Metal }\end{array}$ & $\mathrm{Rp}$ & $945.000,00$ \\
\hline 9 & $\begin{array}{l}\text { Paku Biasa 1/2" - } \\
1 "\end{array}$ & $\mathrm{Rp}$ & $48.000,00$ \\
\hline 10 & GRC Board 9 mm & $\mathrm{Rp}$ & $4.455 .000,00$ \\
\hline \multicolumn{2}{|r|}{ JUMLAH } & $\mathrm{Rp}$ & $64.830 .850,00$ \\
\hline 1 & Pekerja & $\mathrm{Rp}$ & $11.600 .000,00$ \\
\hline 2 & Tukang Besi & $\mathrm{Rp}$ & $10.370 .000,00$ \\
\hline 3 & Kepala Tukang & $\mathrm{Rp}$ & $2.340 .000,00$ \\
\hline 4 & Mandor & $\mathrm{Rp}$ & $1.995 .000,00$ \\
\hline \multicolumn{2}{|r|}{ JUMLAH TOTAL } & $\mathrm{Rp}$ & $91.135 .850,00$ \\
\hline & DIBULATKAN & $\mathrm{Rp}$ & $91.136 .000,00$ \\
\hline
\end{tabular}

(Sumber: Data Olahan)

\subsection{Perencanaan Rangka Atap Kayu}

Direncanakan sebuah gedung yang luas atapnya $16 \mathrm{~m} \times 10,50 \mathrm{~m}$, direncanakan jarak antar kuda-kuda yaitu 2,08 m.

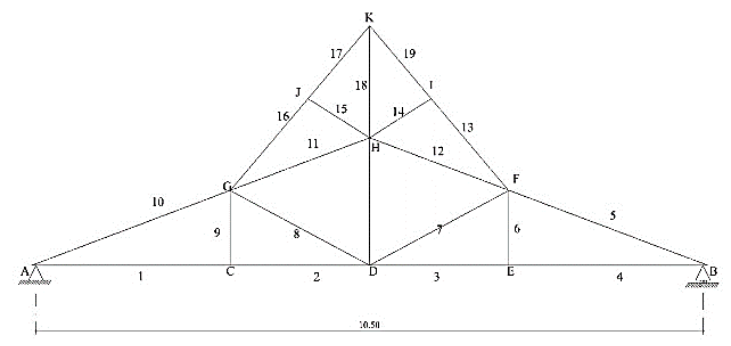

Gambar 3 Rangka Atap Kayu

Hasil perhitungan gaya batang pada rangka atap kayu dapat dilihat pada tabel berikut ini :

Tabel 3 Gaya Batang pada Struktur Rangka Atap Kayu

\begin{tabular}{|l|l|c|c|c|}
\hline \multirow{2}{*}{ No. } & \multirow{2}{*}{$\begin{array}{c}\text { No Batang } \\
(\mathrm{S})\end{array}$} & \multicolumn{2}{|c|}{ Gaya Batang } & $\begin{array}{c}\text { Pjg. } \\
\text { Batang }\end{array}$ \\
\cline { 3 - 5 } & & Tekan & Tarik & $(\mathrm{M})$ \\
\hline 1 & S1 = S4 & - & 1733,37 & 2,625 \\
\hline 2 & S2 = S3 & - & 1733,37 & 2,625 \\
\hline 3 & S5 = S10 & $-1845,98$ & - & 2,860 \\
\hline 4 & S6 = S9 & $-120,45$ & - & 1,100 \\
\hline 5 & S7 = S8 & $-229,53$ & - & 2,290 \\
\hline 6 & S11 = S12 & $-1616,45$ & - & 2,860 \\
\hline 7 & 13 & - & 1102,63 & 2,020 \\
\hline
\end{tabular}

Hasil perhitungan biaya rangka atap kayu dapat dilihat pada tabel berikut :

Tabel 4 Perhitungan Biaya Rangka Atap Kayu

\begin{tabular}{|c|l|rr|}
\hline NO. & \multicolumn{1}{|c|}{ URAIAN } & \multicolumn{2}{|c|}{ JUMLAH HARGA } \\
\hline 1 & Kayu Klas III & $\mathrm{Rp}$ & $13.326 .720,00$ \\
\hline 2 & Papan Klas III & $\mathrm{Rp}$ & $1.516 .680,00$ \\
\hline 3 & Paku Biasa 2" - 5" & $\mathrm{Rp}$ & $307.841,28$ \\
\hline 4 & $\begin{array}{l}\text { Genteng Metal 0,30 } \\
\text { mm }\end{array}$ & $\mathrm{Rp}$ & $18.846 .744,00$ \\
\hline 5 & Paku Skrew & $\mathrm{Rp}$ & $3.167 .520,00$ \\
\hline 6 & Nok Genteng Metal & $\mathrm{Rp}$ & $916.300,00$ \\
\hline & & $\mathrm{Rp}$ & $6.604 .448,00$ \\
\hline 1 & Pekerja & $\mathrm{Rp}$ & $7.239 .178,00$ \\
\hline 2 & Tukang Besi & $\mathrm{Rp}$ & $878.191,20$ \\
\hline 3 & Kepala Tukang & $\mathrm{Rp}$ & $167.583,80$ \\
\hline 4 & Mandor & $\mathrm{Rp}$ & $14.889 .401,00$ \\
\hline & & $\mathrm{Rp}$ & $52.971 .206,28$ \\
\hline & JUMLAH TOTAL & $\mathrm{R}$ & \\
\hline & DIBULATKAN & $\mathrm{Rp}$ & $52.972 .000,00$ \\
\hline
\end{tabular}

(Sumber: Data Olahan)

\subsection{Pembahasan}

Berdasarkan analisa perhitungan terhadap struktur atap baja ringan dan struktur atap kayu didapatkan hasil gaya batang pada struktur rangka atap baja ringan dengan nilai batang maksimum batang tarik bawah adalah 1171,15 Kg pada batang 1 dan 9, nilai batang tekan bawah adalah $-618,28 \mathrm{Kg}$ pada batang 5, nilai maksimum batang tekan atas adalah $-1247,24$ $\mathrm{Kg}$ pada batang 10 dan 19 , nilai maksimum batang tarik atas adalah 494,02 $\mathrm{Kg}$ pada batang 14 dan 15, nilai maksimum batang tekan web adalah $-500,57 \mathrm{Kg}$ pada batang 22 dan 33, dan nilai maksimum batang tarik web adalah 783,65 $\mathrm{Kg}$ pada batang 23 dan 32. Profil yang digunakan adalah Profil C. 75.75.

Sementara, hasil perhitungan gaya batang pada struktur rangka atap kayu, didapatkan nilai batang maksimum batang tarik adalah 1733,37 $\mathrm{Kg}$ pada batang 1, 2, 3, dan 4, sedangkan nilai batang tekan adalah $-1845,98 \mathrm{Kg}$ pada batang 5 dan 10. Dimensi yang digunakan adalah kayu ukuran 7/10 untuk batang tarik dan batang tekannnya.

Berdasarkan hasil perbandingan rangka atap di atas, selisih dari berat rangka atap baja ringan dengan berat rangka atap kayu adalah $354,76 \mathrm{Kg}$ atau sekitar $12,80 \%$. Selisih harga bahan pada rangka atap baja ringan sama dengan harga bahan rangka atap kayu adalah Rp. 26.749.045 atau sekitar 41,26\%. Selisih upah 
pada rangka atap baja ringan dengan upah rangka atap kayu adalah Rp. 11.415 .599 atau sekitar $43,40 \%$. Sedangkan selisih total harga pada rangka atap baja ringan dengan total harga rangka atap kayu adalah Rp. 38.164.000 atau sekitar $41,88 \%$.

Pertambahan berat struktur kuda-kuda baja ringan akan lebih besar dibandingkan dengan pertambahan berat struktur kayu untuk setiap pertambahan lebar bentang kuda-kuda. Hal ini perlu diketahui untuk perencanaan struktur di bawahnya. Walaupun demikian secara umum material kayu akan lebih berat strukturnya dibandingkan dengan baja ringan untuk setiap bentangan yang digunakan. Bentangan yang kecil, biaya rangka atap baja ringan dapat lebih murah dari kayu dengan meminimalkan struktur yang dipasang, sedangkan untuk bentang besar, struktur rangka atap baja ringan cenderung bertambah penggunaan materialnya untuk mengantisipasi lentur yang menjadi kelemahan baja ringan sehingga mengakibatkan biaya rangka atap baja ringan lebih mahal dibandingkan kayu.

Meskipun biaya pembuatan rangka atap baja ringan yang didapat relatif lebih mahal daripada kayu, tetapi waktu yang dibutuhkan untuk pembuatan rangka atap baja ringan lebih cepat dibandingkan rangka atap kayu, selain itu pemakaian material baja ringan memiliki beberapa kelebihan yang tidak dipunyai oleh material kayu seperti tidak mudah terbakar, tahan terhadap karat, dan tahan terhadap serangan rayap.

\section{KESIMPULAN DAN SARAN}

\subsection{Kesimpulan}

1. Hasil desain struktur rangka atap baja ringan menggunakan profil C. 75.75 untuk batang tarik dan batang tekan dengan hasil perhitungan gaya batang yaitu; nilai batang maksimum batang tarik bawah adalah $1171,15 \mathrm{Kg}$ pada batang 1 dan 9, nilai batang tekan bawah adalah $-618,28 \mathrm{Kg}$ pada batang 5, nilai maksimum batang tekan atas adalah 1247,24 Kg pada batang 10 dan 19, nilai maksimum batang tarik atas adalah 494,02 Kg pada batang 14 dan 15, nilai maksimum batang tekan web adalah 500,57 Kg pada batang 22 dan 33, dan nilai maksimum batang tarik web adalah $783,65 \mathrm{Kg}$ pada batang 23 dan 32 . Sedangkan hasil desain struktur rangka atap kayu menggunakan dimensi 7/10 untuk batang tarik dan batang tekan dengan hasil perhitungan gaya batang yaitu; nilai batang maksimum batang tarik adalah $1733,37 \mathrm{Kg}$ pada batang 1 , 2, 3, dan 4 dan nilai batang tekan maksimum adalah $-1845,98 \mathrm{Kg}$ pada batang 5 dan 10 .

2. Hasil perhitungan biaya pada rangka atap baja ringan adalah berjumlah Rp. 91.316.000, sedangkan hasil perhitungan biaya pada rangka atap kayu adalah berjumlah Rp. 52.972.000. Biaya ini berselisih Rp. 38.164.000 atau sekitar $41,88 \%$.

\subsection{Saran}

1. Meskipun biaya pembuatan rangka atap baja ringan yang didapat relatif lebih mahal daripada kayu, tetapi waktu yang dibutuhkan untuk pembuatan rangka atap baja ringan lebih cepat dibandingkan rangka atap kayu, selain itu pemakaian material baja ringan memiliki beberapa kelebihan yang tidak dipunyai oleh material kayu seperti tidak mudah terbakar, tahan terhadap karat, dan tahan terhadap serangan rayap.

2. Sehubungan dengan banyaknya penggunaan baja ringan pada konstruksi bangunan, dalam perhitungan biaya diharapkan adanya angka koefisien analisa harga sesuai dengan analisa SNI.

3. Penggunaan material baja ringan lebih baik dibandingkan dengan kayu mengingat baja ringan yang ramah lingkungan dapat didaur ulang membuat baja ringan turut mendukung program pemerintah dalam menjaga kelestarian hutan.

4. Melihat perkembangan konstruksi baja ringan, semoga ada pembelajaran tambahan mengenai cold-formed steel pada mata kuliah Mekanika Bahan agar lebih menambahkan wawasan wahasiswa/i.

\section{DAFTAR PUSTAKA}

[1] Frick, Heinz, Ir. 2002. Ilmu Konstuksi Bangunan 2. Kanisius, Yogyakarta.

[2] Frick, Heinz, Ir. 1978. Mekanika Teknik 1 \& 2. Kanisius, Yogyakarta, 2007.

[3] Gere \& Timoshenko. 2000. Mekanika Bahan Jilid I \& II. Erlangga, Jakarta.

[4] Kusjuliadi P. Danang. 2007. Ragam Bentuk dan Perawatan Atap. Penebar Swadaya, Jakarta. 
[5] Oentoeng, Ir. 2001. Konstruksi Baja. Andi, Yogyakarta.

[6] Rene Amon, Bruce Knobloch, Atanu Mazumder. 2002. Perencanaan Konstruksi Baja Untuk Insinyur dan Arsitek 2. PT. Pradnya Paramita, Jakarta.

[7] Salmon Charles G, Thon E Jhonson. 2000. Struktur Baja Desain dan Perilaku. PT. Gramedia Pustakan Utama, Jakarta.

[8] Sunggono kh. Ir, 1995, Buku Teknik Sipil. Nova, Bandung.

[9] Sustanto, Kuda-Kuda Konstruksi Kayu. Cipta Science Team.

[10] Wildensyah, Iden. 2010. Rangka Atap Baja Ringan untuk Semua. Alfabeta, Bandung.

[11]Yap Felix. 2001. Konstruksi Kayu. Bima Cipta, Bandung.

[12] Yervi Hesna, Elim Hasan, Harri Novriadi. 2009. Komparasi Penggunaan Kayu Dan Baja Ringan Sebagai Konstruksi Rangka Atap. Jurnal Pendidikan Teknik Sipil. ISSN; 0854-8471. No 32 Vo. 1 Tahun XVI November 2009. Akses; 16 Maret 2016.

[13]Devi Oktarina, Agus Dramawan. Analisa Perbandingan Rangka Atap Kayu Dari Segi Analisis Struktur Dan Anggaran Biaya. Jurnal Konstruksia. No.1 Vo. 7 Tahun Desember 2015. Akses; 6 April 2016.

[14] Mekar Ria Pangribuan. 2014. Baja Ringan Sebagai Pengganti Kayu Dalam Pembuatan Rangka Atap Bangunan Rumah Masyarakat. Jurnal Teknik Sipil dan Ilmu Lingkungan. ISSN; 2355-374X. No. 4 Vo. 2. Tahun Desember 2014. Akses; 6 April 2016.

[15] Fajar Nugroho. 2015. Baja Ringan Sebagai Salah Satu Alternatif Pengganti Kayu Pada Struktur Rangka Kuda-Kuda Ditinjau Dari Segi Biaya. Jurnal Momentum. ISSN; 1693-752X. No. 1 Vo. 17. Tahun Februari 2015. Akses; 7 April 2016.

[16]SNI Tata Cara Perencanaan Konstruksi Kayu Tahun 2002. 